\title{
Application time of chemical thinning with metamitron in 'Sensação' peach trees ${ }^{1}$
}

\author{
Roseli de Mello Farias ${ }^{2}$, Caroline Farias Barreto ${ }^{3 *} \mathbb{D}$, Renan Ricardo Zandoná, \\ Carlos Roberto Martins ${ }^{5}$, Paulo Celso de Mello-Farias ${ }^{3}$
}

10.1590/0034-737X202067010003

\begin{abstract}
Thinning is a cultural practice that leads to balance between fruit yield and quality. It is carried out in a short period of time and requires qualified workforce, whose shortage ends up increasing costs. This study aimed at evaluating the thinning effect of metamitron on peach trees at different periods of time after bloom. The experiment was carried out in a commercial orchard of 'Sensação' peach trees located in Morro Redondo, Rio Grande do Sul (RS) state, Brazil, in 20152016 crops. Treatments were the application of $200 \mathrm{mg} \mathrm{L}^{-1}$ metamitron, 20, 30, 40, 50 and 60 days after full bloom (DAFB), and manual thinning 40 DAFB. Fruit abscission, effective fructification, period of manual and chemical thinning, number of fruits and yield per plant, mean fruit mass and fruit caliber were evaluated. When metamitron was applied 40 DAFB, percentages of fruit abscission and fruit set, besides the number of fruits, were similar to the ones found when manual thinning was carried out. The intensity of the thinning effect of metamitron in peach trees depends on the application period.
\end{abstract}

Keywords: Prunus persica; fruit set; fruit abscission; manual thinning.

\section{INTRODUCTION}

Peach trees exhibit high fruit set, which results in plants with an excessive number of fruits. Hence, the need for fruit thinning practices whose main objective is to better fruit quality and the secondary one is to avoid production alternation. Trees with high load of fruits usually bear little fruits with low commercial value, besides the fact that branches may break as the result of their weight (Pereira \& Raseira, 2014; Giovanaz et al., 2016).

Current thinning practices have been carried out manually in orchards. They enable picked fruits to be selected, i. e., damaged, little and badly located ones are eliminated. However, this practice requires qualified workforce and must be carried out in a short period. Thus, it hinders its execution and, consequently, increases production costs (McArtney \& Obermiller, 2014; Simões etal., 2013).
Other techniques, such as chemical thinning, have been studied as alternatives to replacing manual thinning. Chemical thinning is feasible for peach tree cultures, since it is a fast practice which uses different chemical substances, not only to better fruit quality but also to decrease costs and working time. Regarding peach trees, some products have been studied to thin their fruits (McArtney et al., 2012; Meitei et al., 2013; Giovanaz et al., 2014; Giovanaz et al., 2016). Metamitron, for instance, has become an alternative to managing peach tree thinning (McArtney et al., 2012).

Metamitron has shown adequate results in relation to thinning apple tree fruits by inhibiting photosynthesis (Petri et al., 2016; Goulart et al., 2017; Gabardo et al., 2017a). Fruits, throughout their development, are the main drains of end products of photosynthesis; in the case of interruption or decrease in the photosynthetic rate, fruits

\footnotetext{
Submitted on April $28^{\text {th }}, 2019$ and accepted on November $18^{\text {th }}, 2019$.

${ }^{1}$ This work is part of the first author's doctoral thesis.

${ }^{2}$ Universidade Estadual do Rio Grande do Sul, Rio Grande do Sul, Brazil. roseli-farias@uergs.edu.br

${ }^{3}$ Universidade Federal de Pelotas, Departamento de Fitotecnia, Capão do Leão, Rio Grande do Sul, Brazil.

carol_fariasb@hotmail.com; mellofarias@yahoo.com.br

${ }^{4}$ Universidade Federal de Pelotas, Departamento de Fitossanidade, Capão do Leão, Rio Grande do Sul, Brazil. renan_zandona@ @otmail.com.com

${ }^{5}$ Empresa Brasileira de Pesquisa Agropecuária, Embrapa Clima Temperado, Pelotas, Rio Grande do Sul, Brazil. carlos.r.martins@embrapa.br

*Corresponding author: carol_fariasb@hotmail.com
} 
may fall due to competition (Gabardo et al., 2017a). Metamitron acts on Photosystem II by inhibiting electron transport its effect occurs because it acts on Photosystem II and inhibits electron transport on the chloroplast of plastoquinone $\mathrm{QA}$ to $\mathrm{QB}$. Thus, it decreases production of ATP, NADPH and $\mathrm{CO}_{2}$ fixation, which leads to photosynthesis inhibition (Basak, 2011; Stern, 2014). According to McArtney et al. (2012), there may be excessive fall of fruits from peach and apple trees, depending on the phenological period in which metamitron was applied and on its concentration.

Efficiency in the use of metamitron as a chemical thinner has been associated with certain factors, such as the cultivar, concentration and period of application and weather conditions (McArtney \& Obermiller, 2014; Brunner, 2014; Petri et al., 2016). In the south of Brazil, where most peach-growing regions are located, there is little information on both the chemical thinning of peach tree fruits and on the use of metamitron.

Fruits of the cultivar 'Sensação' have been recommended to be used by industries and to be consumed in natura. Their ripening is precocious and their harvest usually starts in the first fortnight of November in the south of Rio Grande do Sul. Besides, they are commonly large and their yellow firm pulp does not adhere to the stone (Raseira et al., 2014).

According to Pavanello \& Ayub (2012), the ideal chemical thinner is the one that can lead to partial fruit abscission soon after a single application. Several studies have shown satisfactory results of metamitron as a chemical thinner in apple tree cultures (Petri et al., 2016; Goulart et al., 2017; Gabardo et al., 2017a), even though there is no information on peach tree cultures in Brazil. Therefore, this study aimed at evaluating the thinning effect of metamitron on peach trees at different periods of time after bloom in the south of Brazil.

\section{MATERIAL AND METHODS}

The experiment was carried out in a commercial peach tree orchard located in Morro Redondo (31 ${ }^{\circ} 32^{\prime} 40.9^{\prime}$ 'S and 52³4'42.42'”W), Rio Grande do Sul (RS) State, Brazil, in 2015-2016 crops. The cultivar 'Sensação' was grafted on 'Capdeboscq', which was implanted in 2006, conducted in a vase system. Spacing was $5 \mathrm{~m}$ among rows and $2 \mathrm{~m}$ among plants, while density reached 1000 plants ha ${ }^{-1}$. Cultural treatments agreed with recommendations issued by Fachinello et al. (2005). Nitrogen (applied at full bloom, during thinning and postharvest) and potassium (applied at full bloom) fertilization in soil, winter pruning in every July, phytosanitary treatments and control spontaneous plants. These management practices were carried out in all treatments in both years under study.
Values of daily mean temperatures and solar radiation (Figure 2) at the period of metamitron application to peach trees were provided by the meteorological station at the Embrapa Clima Temperado - Cascata, located in Pelotas, RS: 219 and 348 cold hours were registered in 2015 and 2016, respectively. The amount of cold was determined by the Number of Cold Hours (CF) model. Calculation was based on temperatures below or equal to $7.2^{\circ} \mathrm{C}$ (Morais \& Carbonieri et al., 2015).

The experiment was a randomized block design with five replicates of every plant. Treatments were composed of metamitron application - at $200 \mathrm{mg} \mathrm{L}^{-1}$ (McArtney et al., 2012) - 20, 30, 40, 50 and 60days after full bloom (DAFB) and manual thinning 40 DAFB (Table 1). Full bloom (FB) of peach trees took place on August 6th, 2015 and July 25th, 2016. Manual thinning, which was always carried out by the same person, allowed from 10 to $15 \mathrm{~cm}$ among fruits on peach tree branches, depending on plant vigor. It should be mentioned that no manual thinning process was carried out in chemical thinning treatments.

The source of metamitron was the commercial product Goltix $^{\circledR}$ (70\% of chemical ingredient); $0.05 \%$ of Silwet L$77^{\circledR}$ non-ionic surfactant was added to all treatments. Solutions were prepared on the field right before they were applied. Treatments were applied by a Jacto knapsack sprayer whose average water volume was $1000 \mathrm{~L} \mathrm{ha}^{-1}$ and working pressure was 40 psi.

At every application period of the chemical thinner, twenty peaches per treatment were measured so as to have their mean diameters determined by a digital pachymeter. All fruits were cut in half to allow lignin deposition; they were placed in a solution of phloroglucinol $[1 \%(\mathrm{p} / \mathrm{v})$ of

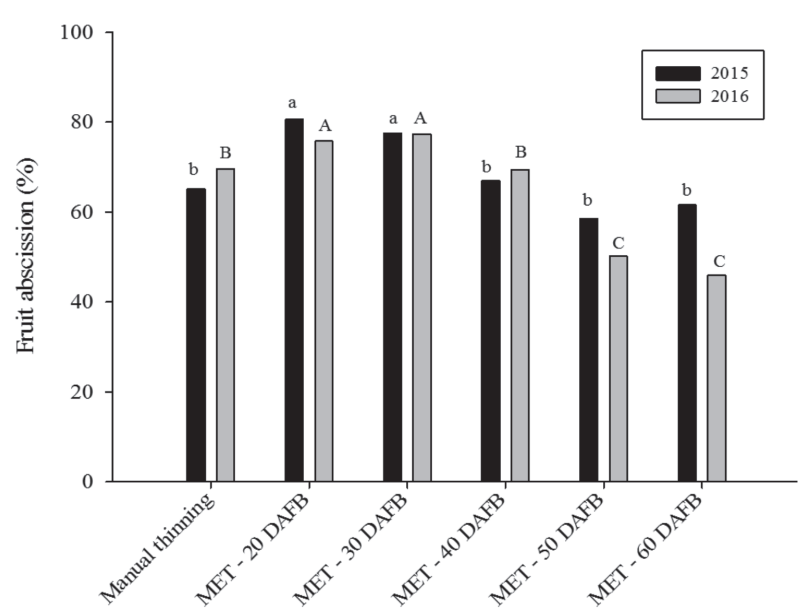

Figure 1: Fruit abscission of 'Sensação' peach trees submitted to manual and chemical thinning with metamitron at different application periods in Morro Redondo, RS, Brazil in 2015 2016 crops. Different small letters show differences in treatments in 2015 whereas different capital letters show differences in treatments in 2016, by the Scott-Knott test at 5\% probability. MET $=$ metamitron. DAFB $=$ days after full bloom.

Rev. Ceres, Viçosa, v. 67, n.1, p. 016-022, jan/feb, 2020 
phloroglucinol, $12 \%$ of $\mathrm{HCl}(\mathrm{v} / \mathrm{v})$ and $85 \%$ of ethanol (v/v)] for an hour, in agreement with the method described by Callahan et al. (2009) (Table 3).

Fruit abscission (\%) was evaluated: every peach tree had six branches randomly marked and fruits were counted before the treatments and at harvest time. Effective fructification (\%) was evaluated on those six branches per plant, i. e., the number of flowers in FB and the number of fruits at harvest time were counted. The number of fruits per plant (fruits plant ${ }^{-1}$ ) and yield per plant $\left(\mathrm{kg} \mathrm{plant}^{-1}\right)$ were measured by counting the total number of fruits at harvest time.

Fruit harvest was carried out at once on November 9th, 2015 (95 DAFB) and on November 10th, 2016 (104 DAFB). After harvest, a sample of 50 fruits per replicate was evaluated regarding mean fruit mass, determined by weighing fruits on a digital scale, results were expressed in grams and fruit caliber, determined by five diameter classes, i. e., above $65 \mathrm{~mm}, 65-60 \mathrm{~mm}, 60-55 \mathrm{~mm}, 55-50 \mathrm{~mm}$ and below $50 \mathrm{~mm}$.

Data were evaluated for normality (Shapiro-Wilk test), submitted to the analysis of variance by the t-test and means were compared by the Scott-Knott test at p d" 0.05 . The Sisvar 5.6 program was used for carrying out the statistical analysis (Ferreira, 2014).

\section{RESULTS AND DISCUSSION}

Fruit abscission of peach trees was influenced by the application period of metamitron. The highest percentages
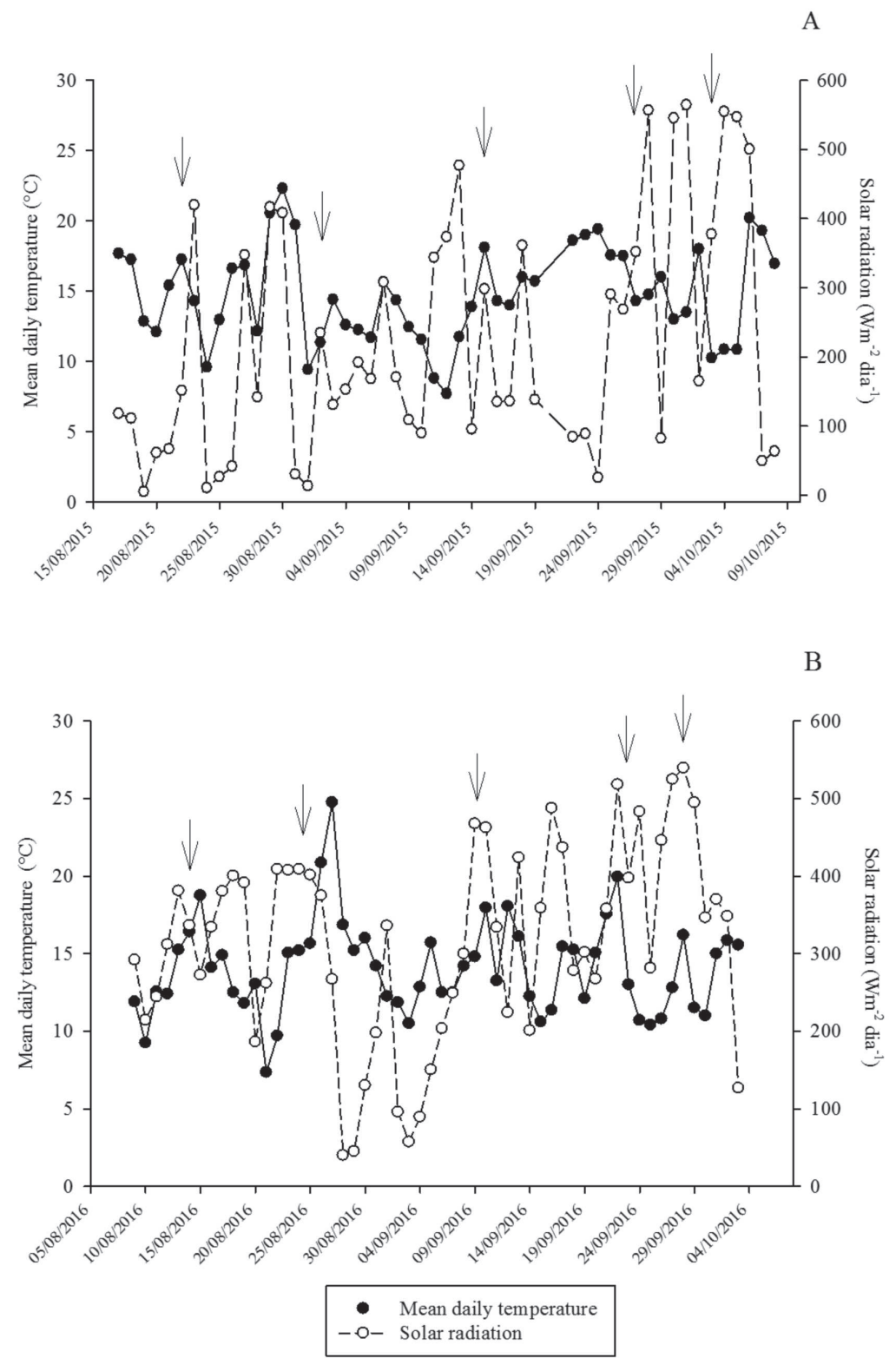

Figure 2: Mean daily temperature and solar radiation throughout the application period of metamitron in 2015 (A) and 2016 (B) in Pelotas, RS, Brazil. Embrapa Clima Temperado - Cascata, Pelotas, RS, Brazil. 
of fruit abscission were found in peach trees thinned with metamitron 20 DAFB in 2015 and 30 DAFB in 2016 (Figure 1). Fruit abscission resulting from metamitron applied 40 DAFB was observed to be similar to the one reached by manual thinning in both years under evaluation. In the 2016 crop, the lowest percentages of fruit abscission were found in plants thinned with metamitron 50 DAFB and 60 DAFB. According to Farias et al. (2019), the highest percentages of fruit abscission in 'Maciel' peach trees with the use of metamitron occurred 20 and 40 DAFB. They stated that metamitron application to fruits at early stages increases fruit abscission, since lignin has not formed at these stages yet. The fact that metamitron contributed to higher fruit abscission at early stages was also observed in apples (Petri et al., 2016; Gabardo et al., 2017b).

Results of fruit set did not show any significant difference among different application periods of metamitron. In 2015, it ranged from 10.20 to $16.64 \%$, while, in 2016 , it ranged from 14.85 to $21.15 \%$ (Table 2). The genetic characteristic of the 'Sensação' variety is that it has intense bloom and exhibits, on average, from 12 to 14 pairs of floral gems every $25 \mathrm{~cm}$ in length on the branch (Raseira et al., 2014). This condition, associated with good uniformity in plant bloom, may have contributed to make remaining flowers develop fruits. Besides, Figure 2 shows that environmental conditions, regarding temperature, were similar in both years (14-19 $\left.{ }^{\circ} \mathrm{C}\right)$. Even though 'Maciel' peach trees had different behavior from the one in the year of application, they did not exhibit any trend in fruit set in relation to the period in which metamitron was applied (Farias et al., 2019). According to Nava et al. (2009), peach trees usually have high fruit set rates, with the contribution of environmental conditions, such as sunny, mild and dry days during blooming. These authors also state that inadequate climatic conditions, such as temperature, rain and relative humidity, in the blooming period may influence fruit establishment and lead to diseases in flowers.

According to McArtney \& Obermiller (2014), metamitron changes the photosynthetic apparatus from 7

Table 1: Treatments applied to peach trees in 2015-2016 crops: manual thinning and chemical thinning with metamitron at $200 \mathrm{mg}$ $\mathrm{L}^{-1}$, mean diameter and lignin deposition on peaches at different application periods after full bloom

\begin{tabular}{lcc}
\hline Treatments & Diameter $(\mathbf{m m})$ & Lignin deposition \\
\hline MET - 20 DAFB & $07-09$ \\
MET - 30 DAFB & $14-16$ \\
MET - 40 DAFB - Manual thinning & $19-21$ \\
MET - 50 DAFB & $28-30$ \\
MET - 60 DAFB & $29-31$ \\
\end{tabular}

Table 2: Fruit set and number of fruits per 'Sensação' peach tree submitted to manual thinning and chemical thinning with metamitron at different application periods in Morro Redondo, RS, Brazil in 2015-2016 crops

\begin{tabular}{|c|c|c|c|c|}
\hline \multirow{2}{*}{ Treatments } & \multicolumn{2}{|c|}{ Fruit set $(\%)$} & \multicolumn{2}{|c|}{ Number of fruits per plant } \\
\hline & 2015 & 2016 & 2015 & 2016 \\
\hline Manual thinning & $15.77^{\mathrm{ns}}$ & $14.85^{\mathrm{ns}}$ & $483 \mathrm{~b}$ & $424^{\mathrm{ns}}$ \\
\hline MET - 20 DAFB & 15.62 & 21.15 & $574 \mathrm{a}$ & 559 \\
\hline MET - 30 DAFB & 16.64 & 19.75 & $445 \mathrm{~b}$ & 494 \\
\hline MET - 40 DAFB & 15.41 & 16.41 & $456 \mathrm{~b}$ & 586 \\
\hline MET - 50 DAFB & 15.40 & 19.71 & $579 \mathrm{a}$ & 599 \\
\hline MET - 60 DAFB & 10.20 & 16.76 & $309 \mathrm{c}$ & 589 \\
\hline$\overline{\mathrm{CV}(\%)}$ & 34.44 & 21.98 & 21.75 & 22.17 \\
\hline
\end{tabular}

Means followed by the same small letter do not differ by the Scott-Knott test at $5 \%$ probability. MET $=$ metamitron. DAFB $=$ days after full bloom. $\mathrm{CV}=$ Coefficient of variation. $\mathrm{ns}=$ not significant. 
to 10 days after its application and decreases electron transport rates up to $60 \%$. Petri et al. (2013) state that the response of chemical thinners in apple trees depends on the interaction between genotype and weather conditions, mainly temperature and solar radiation, which are intrinsic to every production region. Concerning weather conditions, Figure 2 shows that temperature amplitudes were similar in both crops; however, amplitude of solar radiation in the first harvest was greater than in the second one. At applications periods, temperatures ranged from 14 to $18^{\circ} \mathrm{C}(2015)$ and from 15 to $19^{\circ} \mathrm{C}(2016)$, while radiation ranged between 200 and $550 \mathrm{Wm}^{-2} \mathrm{day}^{-1}$ (2015) and between 400 and $530 \mathrm{Wm}^{-2}$ day $^{-1}$ (2016). Thus, behavior of peach trees, which is similar to the one of apple trees (Petri et al., 2013), clearly shows that results of chemical thinners depend on genotype interaction and climatic conditions. For instance, high temperatures - above 24 ${ }^{\circ} \mathrm{C}$ - at blooming and pre-blooming periods delay the development of eggs and damage pollen, thus, affecting fruit set in 'Granada' peach trees, but not affecting 'Maciel' cultivars (Couto et al., 2010). Oscillation of solar radiation and temperature in the 2016 crop may have determined the lowest fruit abscission rate in the most advanced stages of floral development (50 and 60 DAFB), i. e., it may have decreased the thinning effect. Another example of the influence of solar radiation takes place in less vigorous plants, since it is better distributed inside the crown, a fact that favors increase in flower buds (Tomaz et al., 2010).

The number of fruits and yield per plant were affected by the application period of metamitron in the 2015 crop (Tables 2 and 3). The highest number of fruits was found in peach trees which were thinned with metamitron 20 and 50 DAFB, whereas the lowest number of fruits was found in those plants submitted to metamitron application 60 DAFB (Table 2). Plants thinned with metamitron 60 DAFB borne fewer fruits per plant; diameters ranged between 29 and $31 \mathrm{~mm}$ (Table 1). However, their fruits had high mean mass (Table 3) and high percentage of fruits in the class above $65 \mathrm{~mm}$ (Figure 3). Decrease in fruits per plant favors the balance between source and drain, minimizes consumption of reserves and gibberellin synthesis, besides contributing to yield fruits with high mass (Costa et al., 2013; Greene \& Costa, 2013). Metamitron acts on Photosystem II by inhibiting electron transport (Basak, 2011; Stern, 2014), i. e., photosynthetic inefficiency decreases production of carbohydrates that are needed for fruit fixation.

Photosynthesis is controlled by environmental factors, such as temperature and luminosity (Dotto et al., 2017). As a result, variation in results of effects of metamitron on numbers of fruits and production in both years may be related to the low temperature and solar radiation in 2015. This fact, associated with inhibition of electron transport in PSII caused by metamitron may have led to deficiency in the photosynthetic rate and changes in the relation between the source and drain of plants, since it was higher than the one found in 2016. Thus, in conditions of radiation deficiency, effects of metamitron may be potentialized and cause more fruit abscission.

The highest mean fruit mass was found in plants thinned with metamitron 20, 30 and 60 DAFB in 2015, whereas fruit mass was higher when manual thinning and thinning with metamitron 20 and 40 DAFB were carried out in 2016 (Table 3). Similar behavior was found in both crops as the result of thinning with metamitron 20 DAFB, when the highest mean peach mass was reached. It may be due to the fact that, at this time, lignin has not formed yet and fruit diameters range from 7 to $9 \mathrm{~mm}$ (Table 1).

Table 3 shows that lignin formed in peaches 40 DAFB, when they started to get pink. Giovanaz et al. (2015) observed that thinning with abscisic acid in 'Chiripa' peach trees resulted in a small number of fruits and effective fructification when it is carried out $40 \mathrm{DAFB}$, during fruit lignin development. The authors also reported that conducting chemical thinning before lignin development

Table 3: Mean fruit mass and yield per plant of 'Sensação' peach trees submitted to manual thinning and chemical thinning with metamitron at different application periods in Morro Redondo, RS, Brazil in 2015-2016 crops

\begin{tabular}{|c|c|c|c|c|}
\hline \multirow{2}{*}{ Treatments } & Mean fruit mass (g) & Yield per plant $(\mathrm{Kg})$ & \multirow[b]{2}{*}{2015} & \multirow[b]{2}{*}{2016} \\
\hline & 2015 & 2016 & & \\
\hline Manual thinning & $83.51 \mathrm{~b}$ & $83.90 \mathrm{a}$ & $40.33 \mathrm{a}$ & $35.50^{\mathrm{ns}}$ \\
\hline MET - 20 DAFB & $87.04 \mathrm{a}$ & $74.53 \mathrm{a}$ & $49.95 \mathrm{a}$ & 41.60 \\
\hline MET - 30 DAFB & $87.19 \mathrm{a}$ & $69.45 \mathrm{~b}$ & $38.80 \mathrm{a}$ & 34.30 \\
\hline MET - 40 DAFB & $79.97 \mathrm{~b}$ & $74.48 \mathrm{a}$ & $36.46 \mathrm{a}$ & 41.65 \\
\hline MET - 50 DAFB & $74.59 \mathrm{~b}$ & $62.49 \mathrm{~b}$ & $43.18 \mathrm{a}$ & 37.44 \\
\hline MET - 60 DAFB & $90.63 \mathrm{a}$ & $65.32 \mathrm{~b}$ & $28.05 \mathrm{~b}$ & 38.45 \\
\hline $\mathrm{CV}(\%)$ & 8.33 & 14.25 & 19.75 & 18.84 \\
\hline
\end{tabular}

Means followed by the same small letter do not differ by the Scott-Knott test at $5 \%$ probability. MET $=$ metamitron. DAFB $=$ days after full bloom. $\mathrm{CV}=$ Coefficient of variation. $\mathrm{ns}=$ not significant. 

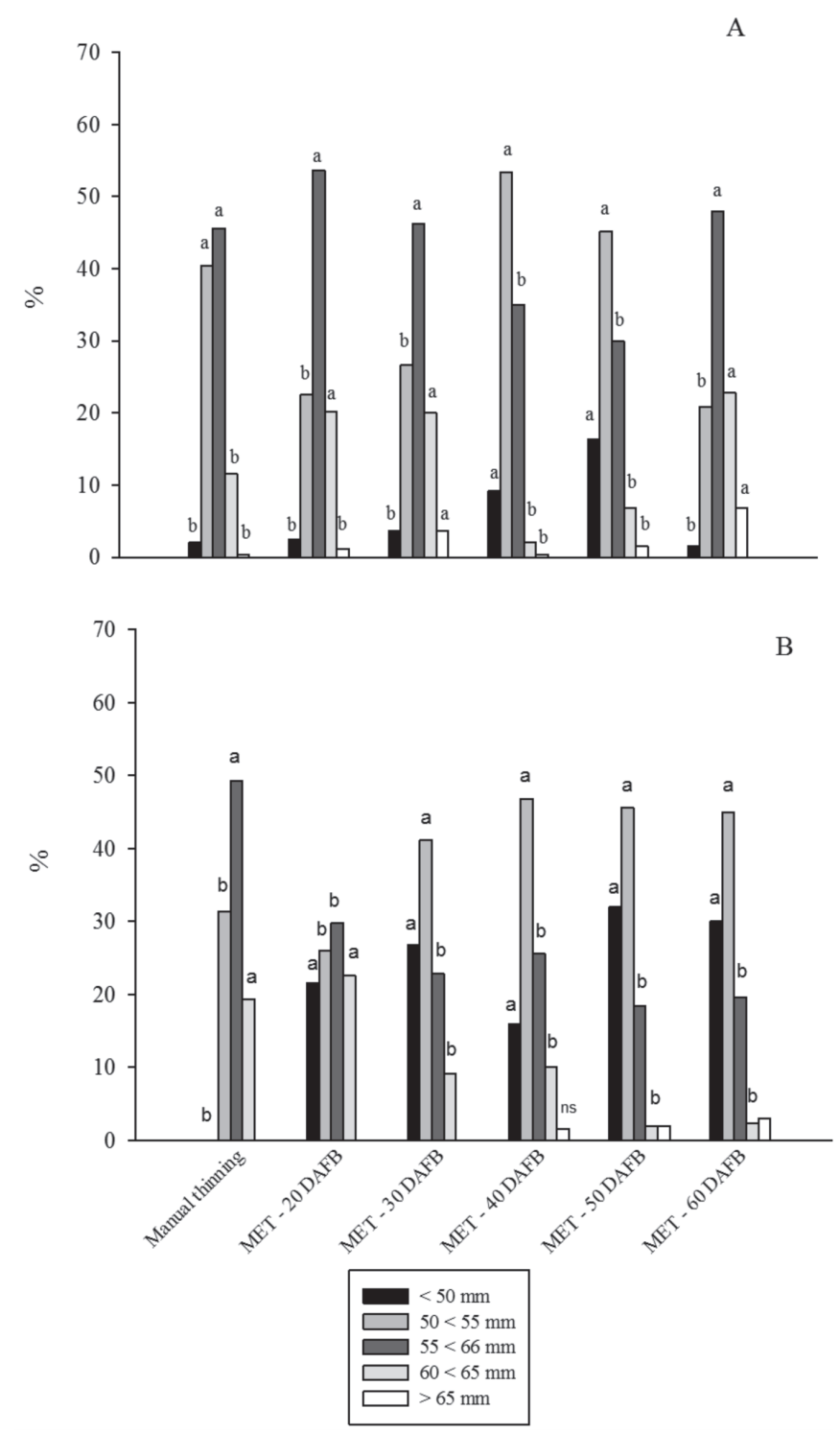

Figure 3: Class of peach fruits submitted to manual thinning and chemical thinning with metamitron at different application periods after full bloom, in Morro Redondo, RS, Brazil in 2015 (A) and 2016 (B) crops. DAPF = days after full bloom. Means followed by the same small letter do not differ by the Scott-Knott test at $5 \%$ probability. ns $=$ not significant.

leads to decrease in the culture load, which may be due to the fact that these plants consume more energy in this phase to form the endocarp and, consequently, the resulting deficit in carbohydrates may favor chemical thinning.

There was no difference in yield per peach tree, whose values ranged between 36.53 and $49.35 \mathrm{~kg}$, except when metamitron was applied 60 DAFB in 2015 (Table 3). Despite the high fruit mass found when metamitron was applied 60 DAFB in 2015 yield did not correspond to it, due to the small number of fruits per plant in this treatment. In 2016, thinning treatments did not show any difference regarding yield per plant. Productivity and mean fruit mass of fruits borne by 'Maciel' cultivars were not affected by metamitron, regardless of its application period (Farias et al., 2019).
Peaches were classified into five classes, depending on fruit diameters, in both crops under evaluation (Figure 3 ). The $<50 \mathrm{~mm}$ class showed the lowest percentage of fruits in manual thinning and in chemical thinning with metamitron 20, 30 and 60 DAPF in 2015, and in manual thinning in 2016. The highest percentage of fruits yielded by plants which were submitted to manual thinning was classified into the category from $55<60 \mathrm{~mm}$, in both crops. Metamitron applied to peach trees 30 and 60 DAFB contributed to the high percentage of fruits in the category $>65 \mathrm{~mm}$ in 2015 .

Application periods of chemical thinning in peach trees must take into consideration that precocious thinning may pose risks when there is late frost. However, the high cost of manual thinning and lack of workforce in peach-growing regions should be taken into account. 


\section{CONCLUSIONS}

Intensity of the thinning effect of metamitron in peach trees depends on the application period. Metamitron applied to 'Sensação' peach trees 40 DAFB enables them to exhibit percentages of fruit abscission, fruit set and number of fruits per plant which are similar to the ones of manual thinning. Thinning with metamitron is effective in 'Sensação' peach trees when it is carried out up to 40 DAFB.

\section{ACKNOWLEDGMENTS}

The authors thank the National Council of Scientific and Technological Development CNPq for the financial support for this research. There is no conflict of interest in the conduct and publication of the work.

\section{REFERENCES}

Basak A (2011) Efficiency of fruitlet thinning in apple "Gala must" by use of Metamitron and artificial shading. Journal of Fruit and Ornamental Plant Research, 19:51-62.

Brunner P (2014) Impact of metamitron as a thinning compound on apple plants. Acta Horticulturae, 1042:173-181.

Callahan AN, Dardick C \& Scorza R (2009) Characterization of 'Stoneless': A naturally occurring, partially stoneless plum cultivar. Journal of the American Society for Horticultural Science, 134:120-125.

Couto M, Raseira MCB, Herter FG \& Silva JB (2010) Influence of high temperatures at blooming time on pollen production and fruit set of peach cvs. Maciel and Granada. Acta Horticulturae, 872:225-230

Costa G, Blanke MM \& Widmer A (2013) Principles of thinning in fruit tree crops - needs and novelties. Acta Horticulturae, 998:17-26.

Dotto M, Pirola K, Américo WJ, Radaelli JC, Antunes LEC \& Citadin I (2017) Physiological and sensorial aspects of peach fruits cv. Chimarrita depending on the season and management of green pruning. Brazilian Journal of Agriculture, 92:261-270.

Fachinello JC, Tibola CS, Picolotto L, Rossi A \& Rufato L (2005) Produtividade e qualidade de pêssegos obtidos nos sistemas de produção integrada e convencional. Revista Brasileira de Fruticultura, 27:64-67.

Farias RM, Martins CM, Barreto CF, Giovanaz MA, Malgarim MB \& Mello-Farias P (2019) Time of metamitron application and concentration in the chemical thinning of 'Maciel' peach. Revista Brasileira de Fruticultura, 41:e-017.

Ferreira DF (2014) Sisvar: a Guide for its Bootstrap procedures in multiple comparisons. Ciência e Agrotecnologia, 38:109-112.

Gabardo GC, Petri JL, Hawerroth FJ, Couto M, Argenta LC \& Kretzschmar AA (2017a) Use of metamitron as an apple thinner. Revista Brasileira de Fruticultura, 39:e514.

Gabardo GC, Kretzschmar AA, Petri JL, Couto M, Hawerroth FJ \& Silva CDS (2017b) Taxa fotossintética em macieiras tratadas com metamitron. Revista Eletrônica Científica UERGS, 3:617633.

Giovanaz MA, Fachinello JC, Goulart C, Radünz AL, Amaral PA \& Weber D (2014) Produção e qualidade de pêssegos, cv. Jubileu, com uso de fitorreguladores. Revista Ceres, 61:552-557.
Giovanaz MA, Spagnol D, Bartz J, Pasa MS, Chaves FC \& Fachinello JC (2015) Abscisic acid as a potential chemical thinner for peach. Pesquisa Agropecuária Brasileira, 50:989-992.

Giovanaz MA, Fachinello JC, Spagnol D, Weber D \& Carra B (2016) Gibberellic acid reduces flowering and time of manual thinning in 'Maciel' peach trees. Revista Brasileira de Fruticultura, 38:01-10.

Goulart G, Andrade SB, Bender A, Shiavon AV, Aguiar GA \& Malgarim MB (2017) Metamitron and different plant growth regulators combinations in the chemical thinning of 'Eva' apple. Journal of Experimental Agriculture International, 18:01-06.

Greene DW \& Costa G (2013) Fruit Thinning in Pome- and StoneFruit: State of the Art. Acta Horticulturae, 998:93-102.

Lafer G (2010) Effects of chemical thinning with metamitron on fruit set, yield and fruit quality of 'Elstar'. Acta Horticulturae, 884:531-536.

McArtney SJ, Obermiller JD \& Arellano C (2012) Comparison of the Effects of Metamitron on Chlorophyll Fluorescence and Fruit Set in Apple and Peach. HortScience, 47:509-514.

McArtney SJ \& Obermiller JD (2014) Use of shading and the psii inhibitor Metamitron to investigate the relationship between carbohydrate balance and chemical thinner activity in apples. Acta Horticulturae, 1042:27-31.

Meitei SB, Patel RK, Deka BC, Deshmukh NA \& Singh A (2013) Effect of chemical thinning on yield and quality of peach cv. Flordasun. African Journal of Agricultural Research, 8:33583565 .

Morais H \& Carbonieri J (2015) Horas e unidades de frio em pomares de maçã com diferentes microclimas. Revista Brasileira de Fruticultura, 37:01-12.

Nava GA, Dalmago GA, Bergamaschi H, Paniz R, Santos RA \& Marodin GAB (2009) Effect of high temperatures in the preblooming and blooming periods on ovule formation, pollen grains and yield of Granada peach. Scientia Horticulturae, 122:37-44.

Pavanello AP \& Ayub RA (2012) Aplicação de Ethephon no raleio químico de ameixeira e seu efeito sobre a produtividade. Revista Brasileira de Fruticultura, 34:309-316.

Pereira JFM \& Raseira A (2014) Raleio. In: Raseira MCB, Pereira JFM \& Carvalho FLC (Eds.) Pessegueiro. Brasília, Embrapa. p.309-327.

Petri JL, Hawerroth FJ, Berenhauser G \& Couto M (2013) Raleio químico em macieiras 'Fuji suprema' e 'Lisgala'. Revista Brasileira de Fruticultura, 35:170-182.

Petri JL, Couto M, Gabardo GC, Francescatto P \& Hawerroth FJ (2016) Metamitron replacing carbaryl in post bloom thinning of apple trees. Revista Brasileira de Fruticultura, 38:01-14.

Raseira MCB, Nakasu BH \& Barbosa W (2014) Cultivares: descrição e recomendação. In: Raseira MCB, Pereira JFM \& Carvalho FLC (Eds.) Pessegueiro. Brasília, Embrapa. p.73-141.

Simões MP, Vuleta I \& Belusic (2013) Monda mecânica de flores com equipamento electro'flor em pessegueiros da cultivar 'Rich Lady'. Revista de Ciências Agrárias, 36:297-302.

Stern RA (2014) The photosynthesis inhibitor metamitron is an effective fruit-let thinner for 'Gala' apple in the warm climate of Israel. Scientia Horticulturae, 178:163-167.

Tomaz ZFP, Lima CSM, Gonçalves MA, Rufato L \& Rufato ADR (2010) Crescimento vegetativo, floração e frutificação efetiva do pessegueiro 'Jubileu' submetido a diferentes comprimentos de interenxertos. Pesquisa Agropecuária Brasileira, 45:973-979. 